\title{
Lotus glaber Mill. Induced autotetraploid: new forage resource for the Flooding Pampas
}

\author{
M. Barufaldi ${ }^{1}$, Y. Villacampa ${ }^{2}$, P. Sastre-Vázquez ${ }^{3}$, \\ F. García-Alonso ${ }^{2} \&$ J. A. Reyes ${ }^{2}$ \\ ${ }^{1}$ Cátedra de Genética y Fitotecnia, \\ Facultad de Agronomía de Azul-UNCPBA, Buenos Aires, Argentina \\ ${ }^{2}$ Departamento de Matemática Aplicada, Universidad de Alicante, \\ Alicante, Spain \\ ${ }^{3}$ Área de Matemáticas, Facultad de Agronomía de Azul-UNCPBA, \\ Buenos Aires, Argentina
}

\begin{abstract}
Lotus glaber Mill., a perennial leguminous forage plant endemic to Europe and introduced into Argentina in 1930, has adapted to the Flooding Pampas region's ecological characteristics, successfully becoming part of the native vegetation. Given its high nutritional value and the fact that it does not cause meteorism, this plant has great potential for increasing the productivity and quality of the Pampas grazing land. In Azul, a Buenos Aires province, an L. glaber genetic improvement programme resulted in an induced autotetraploid population called Leonel, through the use of colchicine. In addition to preserving the species' valuable characteristics, this population has a series of significant morphological modifications compared to diploid populations. This paper compares the Leonel population in terms of the length and width of its central foliolae (LCF and WCF), its area (A) and the length/width ratio (L/W) of the central foliolae of the first expanded leaf from the apex, during the following seasons: mid-winter (1), late winter (2), and late spring (3) of 2006. Variance analyses, in a completely random sample with one factor, seasons, carried out for each variable, detected significant differences (1\%) in all cases. Analysis of the $\mathrm{L} / \mathrm{W}$ ratio has made it possible to determine the foliolae's forms. During the winter period, seasons 1 and 2, the foliolae took a narrowly obovate shape, while in the spring they had an oblanceaolate shape. The results obtained lead to the conclusion that there is a high level of variation in length and width, as well as the foliolae's shape and size.
\end{abstract}

Keywords: Lotus glaber Mill., induced autotetraploid, forage legume, natural pastureland, mathematical modelling. 


\section{Introduction}

Flooding Pampas region of Buenos Aires province, whose surface area totals approximately 9 million hectares, is Argentina's principal cattle-raising region. Eighty-five percent of its livestock feeds on natural pastureland, and the rest on cultivated pastureland (Sácido [1]). In most natural vegetable communities there is a small amount of native leguminous plants that can serve as forage, and the planting of conventional leguminous crops is limited by poor soil quality (García et al [2]).

Lotus glaber Mill., commonly known as narrowleaf birdsfoot trefoil, is a perennial leguminous plant suitable for forage endemic to Europe. It was introduced in Argentina in about 1930, and it spread naturally in the pastureland of Flooding Pampas. During the 1970s, it attracted interest as a forage species, given its nutritional qualities and the fact that it does not cause meteorism.

Numerous authors consider it an improved natural pastureland species, of great importance for the region's livestock breeding (Barufaldi et al. [3]).

The soils this species occupies have poor fertility and drainage, moderate sodium levels and low concentrations of available phosphorus. Frequent disturbances in local vegetation, such as agricultural work, overgrazing, fires in communities of tussock paspulum (Paspalum quadrifarium), and floods, have facilitated L. glaber's colonisation (Juan et al. [4], Miñon et al. [5]). Its growth pattern is spring-summer-autumn, growing intensely in spring and early summer, later decaying with flowering and recovering quickly in the fall after going to seed. The fodder produced has a high nutritional value that varies little throughout the cycle, even during the seed-bearing stage.

L. glaber is a diploid species whose chromosome number is $2 \mathrm{n}=2 \mathrm{x}=12$. Its growth is semi-prostrate to prostrate, it has a pivotal root with lateral branching, and its stalk is round at the base and squared at the section of active growth. Its inflorescence is a typical umbellate, with 2-8 flowers joined by a short pedicel to a long peduncle.

Each leaf consists of five foliolae, which are generally oblanceolate, ellipticoblanceolate or narrowly obovate (Kirbride [6]).

Induced polyploids have been used in some forage species such as Dactylis glomerata ssp. lusitanica, Lolium perenne, Lolium multiflorum, Secale cereale, Trifolium pratense, Trifolium hybridum, and Lotus pedunculatus, for the purpose of obtaining improved autotetraploid cultivars or to generate interspecific hybrids. In general, the induced autotetraploids in ryegrass, rye, clovers and big trefoil show better establishment, higher in vitro digestibility and forage production, and better performance in response to such adverse factors as disease, frost and drought, than corresponding diploids.

In Argentina, there have been scant efforts to genetically improve L. glaber, which has resulted in poor availability of cultivars. There are few antecedents for obtaining induced tetraploid plants $(2 n=4 x=24)$ through the chromosomal doubling of diploid plants, and no tetraploid cultivars are on the market.

In Azul, a Buenos Aires province, an L. glaber genetic improvement programme obtained an induced tetraploid cultivar population called Leonel 
$(2 \mathrm{n}=4 \mathrm{x}=24)$, (Barufaldi et al. [7]). This population was obtained through colchicine treatment of seedlings obtained from seeds collected from naturalised L. glaber populations. The programme aimed to obtain tetraploid cultivars with enhanced productive and health aspects, selected for the Flooding Pampas's normal grazing conditions.

In addition to preserving the species' valuable characteristics, this population exhibits a series of significant morphological modifications compared with diploid populations. In previous articles referring to this improvement programme, increased dry material was detected when compared to a control diploid population (Barufaldi et al. [8]). It could be assumed that this increase is due in part to the larger size of the foliolae in the evaluated tetraploid ("tetraploid cytotype"), compared with diploids ("diploid cytotype"). Furthermore, in another article (Barufaldi et al. [3]) the area of the central foliolae in the Leonel population was studied, and a formula was determined that allows for the estimation of the foliolae's area, based on its width.

Most morphological diversity studies focus on the classification of species and the differences within species on a broad geographical scale, with the goal of generating strategies that optimise in situ preservation and examining inter- and intra-regional morphological diversity specific to species. Moreover, the study of populations' morphological stability is also important when requesting the registration of varieties of agricultural plant species. The programme under way has the long-term objective of achieving an improved cultivar derived from the Leonel germplasm and registering it.

In Argentina, marketing the seed of a new cultivar currently requires its prior registration with the National Seed Institute (INASE). There are two agencies that authorise its distribution: the National Cultivar Register (RNC), which regulates all species; and the Taxation System (RF), which applies only to cultivars from the major agricultural species. The latter is obligatory, authorising the marketing of seeds in the Inspected category, as well as those in the Identified category. All cultivars identified for the first time are registered with the RNC. The legislation in force, Decree No. 2183/91, distinguishes between "new" and "unknown" varieties, on one hand, and "publicly known" varieties. Whoever requests registration of a cultivar must describe its morphological, phenological and health characteristics in a way that distinguishes it from other cultivars, and make a commitment to maintain the material's genetic purity. In the case of $L$. glaber, required information includes data on the typical (central) foliolae, and for this purpose it is necessary to determine: 1) its shape (linear, lanceolate, linear-lanceolate, oblong, oval, or other); 2) its length; and 3) its width.

If the long-term objective is to achieve a new variety and register it, the description of its morphology, among other characteristics, has a clear importance. The central foliolae's features are useful in the characterisation of the germplasm and for genetic and evolutionary studies (Urrea and Singh [9]).

This study evaluated the seasonal stability of the central foliolae of the Leonel induced tetraploid population of Lotus glaber, in regard to size and shape, for the 
purpose of determining whether there is morphological variation within the population during different seasons

\section{Materials and methodology}

All experimental materials and data were utilised in the Azul Agronomy School, Buenos Aires province ( $36^{\circ} 45^{\prime} \mathrm{S}, 59^{\circ} 50^{\prime} \mathrm{W}$ and $132 \mathrm{msm}$ ), Argentina, during 2006.

The plant material was taken from the Leonel population. During the month of March 2006, 200 seeds were left to germinate in accordance with ISTA norms. The seedlings obtained were transplanted in 2-litre plastic planters, with soil and compost; when they reached the height of $15 \mathrm{~cm}$ they were permanently transplanted in 5-litre plastic planters and remained in a greenhouse under optimal temperature and irrigation conditions.

The samples were obtained while the plants were in a vegetative state: season 1 (winter), season 2 (late winter) and season 3, at the start of the reproductive state (late spring). For each season, 40, 61 and 50 planters, respectively, were selected at random. Three stalks were taken at random from each plant, and from each of them the central foliolae corresponding to the first developed (expanded) leaf from the apex was utilised. For each of the foliolae, measurements were taken of: 1) the central foliolae's length in centimetres, from the foliar lamina's point of insertion in the petiole to the foliolae's apex, and 2) the central foliolae's width measured in centimetres at an angle perpendicular to the central nerve of the foliolae's widest point. On the basis of this data, the central foliolae's area was estimated using the model $A f=1.76658 A-0.4990925$ (Barufaldi et al. [3]). The central foliolae's shape is determined by its length and width, following the classification presented by (Hickey [10]).

An analysis of variance has been performed, using a completely random design with one factor - i.e., seasons - and the variables of area, length, width and length/width ratio. Furthermore, for each season considered, linear regressions between length (dependent variable) and width (independent variable) were adjusted

\section{Data analysis}

The results of the variance analysis, applied to a completely random design and a model with a single factor (seasons) for the variables of area, length, width and length/width ratio of the central foliolae, are presented in tables $1-4$.

Significant differences were detected between the three seasons for the four variables studied. The means are compared through Duncan's test, as reflected in tables 5-8.

The sizes of the central foliolae, evaluated according to their area, proved to be significantly different for the three seasons studied. The largest sizes were found in the vegetative states, corresponding to seasons 1 and 2. During season 3 - that is, at the start of the reproductive state - the foliolae were at their smallest size. 
Table 1: ANOVA for the variable: Area of the central foliolae. Dependent variable: Area. Squared =.229 (Adjusted R Squared $=.225$ ).

\begin{tabular}{|c|c|c|c|c|c|}
\hline & $\begin{array}{c}\text { Type III Sum of } \\
\text { Squares }\end{array}$ & df & $\begin{array}{c}\text { Mean } \\
\text { Square }\end{array}$ & F & Sig. \\
\hline Cource & $6,746(\mathrm{a})$ & 2 & 3,373 & 66,607 &, 000 \\
Model & 224,369 & 1 & 224,369 & 4430,973 &, 000 \\
Intercept & 6,746 & 2 & 3,373 & 66,607 &, 000 \\
season & 22,736 & 449 &, 051 & & \\
Error & 253,288 & 452 & & & \\
Total & 29,481 & 451 & & & \\
Corrected & Total & & & & \\
\hline
\end{tabular}

Table 2: $\quad$ ANOVA for the variable: Length of the central foliolae (LCF). Dependent Variable: LCF. R Squared $=.077$ (Adjusted R Squared $=.073)$.

\begin{tabular}{|c|c|c|c|c|c|}
\hline & $\begin{array}{c}\text { Type III Sum of } \\
\text { Squares }\end{array}$ & df & $\begin{array}{c}\text { Mean } \\
\text { Square }\end{array}$ & F & Sig. \\
\hline Source & $1,521(\mathrm{a})$ & 2 &, 760 & 18,810 &, 000 \\
Morrected & 935,759 & 1 & 935,759 & 23147,731 &, 000 \\
Intercept & 1,521 & 2 &, 760 & 18,810 &, 000 \\
Season & 18,191 & 450 &, 040 & & \\
Error & 978,768 & 453 & & & \\
Total & 19,712 & 452 & & & \\
Corrected & Total & & & & \\
\hline
\end{tabular}

Table 3: ANOVA for the variable: Width of the central foliolae (WCF). Dependent Variable: WCF. R Squared $=.237$ (Adjusted R Squared $=.233)$.

\begin{tabular}{|c|c|c|c|c|c|}
\hline & & & & & \\
Source & Type III Sum of Squares & df & Mean Square & F & Sig. \\
\hline Corrected Model & $2,259(\mathrm{a})$ & 2 & 1,130 & 69,735 &, 000 \\
Intercept & 208,201 & 1 & 208,201 & 12853,395 &, 000 \\
season & 2,259 & 2 & 1,130 & 69,735 &, 000 \\
Error & 7,289 & 450 &, 016 & & \\
Total & 219,969 & 453 & & & \\
Corrected Total & 9,548 & 452 & & & \\
\hline
\end{tabular}

For the LCF, the largest measurement of $1.53 \mathrm{~cm}$ was taken in season 3, which was significantly different from the other two seasons, which did not exhibit any differences among themselves. As for WCF, significant differences were detected for all the seasons (1, 2 and 3), with measurements of $0.68 \mathrm{~cm}$, $0.78 \mathrm{~cm}$ and $0.60 \mathrm{~cm}$, respectively. 
Table 4: ANOVA for the variable: length/width (L/W) of the central foliolae. Dependent Variable: L/W. R Squared $=.416$ (Adjusted R Squared $=.413)$.

\begin{tabular}{|c|c|c|c|c|c|}
\hline Source & $\begin{array}{c}\text { Type III Sum of } \\
\text { Squares }\end{array}$ & df & $\begin{array}{c}\text { Mean } \\
\text { Square }\end{array}$ & F & Sig. \\
\hline Corrected & $41,226(\mathrm{a})$ & 2 & 20,613 & 160,115 &, 000 \\
Model & 2118,421 & 1 & 2118,421 & 16455,418 &, 000 \\
Intercept & 41,226 & 2 & 20,613 & 160,115 &, 000 \\
season & 57,932 & 450 &, 129 & & \\
Error & 2307,855 & 453 & & & \\
Total & 99,157 & 452 & & & \\
Corrected & & & & & \\
Total & & & & & \\
\hline
\end{tabular}

Table 5: $\quad$ Duncan's test for the variable area.

\begin{tabular}{|c|c|c|c|c|}
\hline \multicolumn{5}{|c|}{ Area of central foliolae } \\
Alpha 0.001 \\
\hline \multirow{2}{*}{ season } & $\mathrm{N}$ & \multicolumn{3}{|c|}{ Subset } \\
& & 1 & 2 & 3 \\
\hline 3,00 & 150 &, 5586 & & \\
1,00 & 182 & &, 7093 & \\
2,00 & 120 & & &, 8765 \\
Sig. & & 1,000 & 1,000 & 1,000 \\
\hline
\end{tabular}

Table 6: Duncan's test for the variable LCF.

\begin{tabular}{|l|c|r|r|}
\hline \multicolumn{3}{|c|}{$\begin{array}{c}\text { Length of central foliolae: LCF } \\
\text { Alpha } 0,001\end{array}$} \\
\hline \multirow{2}{*}{ season } & $\mathrm{N}$ & \multicolumn{2}{|c|}{ Subset } \\
\cline { 3 - 4 } & & 1 & 2 \\
\hline 1,00 & 183 & 1,3973 & \\
2,00 & 120 & 1,4463 & \\
3,00 & 150 & & 1,5325 \\
Sig. & &, 038 & 1,000 \\
\hline
\end{tabular}

Table 7: Duncan's test for the variable WCF.

\begin{tabular}{|c|c|c|c|c|}
\hline \multicolumn{5}{|c|}{ Width of central foliolae: WCF } \\
Alpha 0.001 \\
\hline \multirow{2}{*}{ season } & $\mathrm{N}$ & \multicolumn{3}{|c|}{ Subset } \\
& & 1 & 2 & 3 \\
\hline 3,00 & 150 &, 5980 & & \\
1,00 & 183 & &, 6842 & \\
2,00 & 120 & & &, 7820 \\
Sig. & & 1,000 & 1,000 & 1,000 \\
\hline
\end{tabular}


Table 8: $\quad$ Duncan's test for the variable L/W.

\begin{tabular}{|c|c|c|c|c|}
\hline \multicolumn{5}{|c|}{ Length/Width ratio: L/W } \\
\hline \multirow{2}{*}{ season } & \multirow{2}{*}{$\mathrm{N}$} & \multicolumn{3}{|c|}{ Subset } \\
\cline { 3 - 5 } & & 1 & 2 & 3 \\
\hline 2,00 & 120 & $\begin{array}{c}1,87 \\
63\end{array}$ & & \\
1,00 & 183 & & 2,0885 & \\
3,00 & 150 & & & 2,6195 \\
Sig. & & 1,00 & 1,000 & 1,000 \\
\hline
\end{tabular}

Analysis of the L/W ratio allowed for determination of the foliolae's shapes. During the winter period, seasons 1 and 2, the foliolae were narrowly obovate, while during the spring they were oblanceaolate.

These results lead to the conclusion that there is a high level of variation, in length and width, as well as the foliolae's shape and size, during the states of vegetative development (seasons 1 and 2) and the start of the reproductive state (season 3), as can be observed in table 9.

Table 9: $\quad$ Measurements of variables studied for different seasons.

\begin{tabular}{|c|c|c|c|c|c|}
\hline Seasons & Length & Width & L/W & Shape & Area \\
\hline 1 Winter & 1,3973 &, 6842 & 2,0885 & narrowly obovate &, 7093 \\
$\begin{array}{c}\text { 2 Late } \\
\text { Winter }\end{array}$ & 1,4463 &, 7820 & 1,8763 & narrowly obovate &, 8765 \\
$\begin{array}{c}\text { 3 Late } \\
\text { Spring }\end{array}$ & 1,5325 &, 598 & 2,6195 & oblanceolate &, 5586 \\
\hline
\end{tabular}

\subsection{Mathematical modelling}

Mathematical models have been determined for calculating the ratio of foliolae length as a function of width (length/width). Of the models studied, the best were linear models without intercept - i.e., linear regressions expressed by straight lines that pass through the origin. In all cases, the significance tests of the regressions for each season detected that the variable in question (width) made a significant contribution. Tables 10-12 show ANOVA, the estimates of the mathematical models and $\mathrm{R}^{2}$.

Figure 1 shows the linear regressions without intercept for each season. 
Table 10: LCF Season 1: ANOVA, the estimates of the mathematical models and $\mathrm{R}^{2}$.

\begin{tabular}{|c|c|c|c|c|c|c|}
\hline & \multicolumn{2}{|c|}{ Sum of Squares } & $\mathrm{df}$ & $\begin{array}{l}\text { Mean } \\
\text { Square }\end{array}$ & $\mathrm{F}$ & Sig. \\
\hline Regression & \multirow{3}{*}{\multicolumn{2}{|c|}{$\begin{array}{l}355,801 \\
8,339 \\
364,140\end{array}$}} & 1 & 355,801 & 7765,326 &, 000 \\
\hline Residual & & & 182 &, 046 & & \\
\hline Total & & & 183 & & & \\
\hline \multicolumn{7}{|c|}{$\begin{array}{l}\text { The independent variable is WCF. } \\
\text { The equation was estimated without the constant term. } \\
\text { Coefficients }\end{array}$} \\
\hline & \multicolumn{2}{|c|}{$\begin{array}{l}\text { Unstandardized } \\
\text { Coefficients }\end{array}$} & $\begin{array}{l}\text { Standardized } \\
\text { Coefficients }\end{array}$ & & & \\
\hline & B & $\begin{array}{l}\text { Std. } \\
\text { Error }\end{array}$ & Beta & $\mathrm{t}$ & Sig. & \\
\hline WCF & 1,998 &, 023 & ,988 & 88,121 &, 000 & \\
\hline $\mathrm{R}$ & \multicolumn{2}{|c|}{ R Square } & $\begin{array}{l}\text { Adjusted R } \\
\text { Square }\end{array}$ & $\begin{array}{l}\text { Std. Error } \\
\text { of the } \\
\text { Estimate }\end{array}$ & & \\
\hline ,988 & \multicolumn{2}{|c|}{,977 } & ,977 & ,214 & & \\
\hline
\end{tabular}

Table 11: LCF Season 2: ANOVA, the estimates of the mathematical models and $\mathrm{R}^{2}$.

\begin{tabular}{|c|c|c|c|c|c|c|}
\hline & \multicolumn{2}{|c|}{ Sum of Squares } & df & $\begin{array}{l}\text { Mean } \\
\text { Square }\end{array}$ & $\mathrm{F}$ & Sig. \\
\hline Regression & \multicolumn{2}{|c|}{250,427} & 1 & 250,427 & 7331,521 &, 000 \\
\hline Residual & \multirow{2}{*}{\multicolumn{2}{|c|}{$\begin{array}{c}4,065 \\
254,492\end{array}$}} & 119 & ,034 & & \\
\hline Total & & & 120 & & & \\
\hline \multicolumn{7}{|c|}{$\begin{array}{l}\text { The independent variable is WCF. } \\
\text { The equation was estimated without the constant term. } \\
\text { Coefficients }\end{array}$} \\
\hline & \multicolumn{2}{|c|}{$\begin{array}{l}\text { Unstandardized } \\
\text { Coefficients }\end{array}$} & $\begin{array}{c}\text { Standardized } \\
\text { Coefficients }\end{array}$ & & & \\
\hline & B & $\begin{array}{l}\text { Std. } \\
\text { Error }\end{array}$ & Beta & $\mathrm{t}$ & Sig. & \\
\hline WCF & 1,826 &, 021 & ,992 & 85,624 & ,000 & \\
\hline $\mathrm{R}$ & \multicolumn{2}{|c|}{ R Square } & $\begin{array}{l}\text { Adjusted R } \\
\text { Square }\end{array}$ & $\begin{array}{l}\text { Std. Error } \\
\text { of the } \\
\text { Estimate }\end{array}$ & & \\
\hline ,992 & \multicolumn{2}{|c|}{,984 } & ,984 &, 185 & & \\
\hline
\end{tabular}


Table 12: $\quad$ LCF Season 3: ANOVA, the estimates of the mathematical models and $\mathrm{R}^{2}$.

\begin{tabular}{|c|c|c|c|c|c|c|}
\hline & \multicolumn{2}{|c|}{ Sum of Squares } & $\mathrm{df}$ & $\begin{array}{l}\text { Mean } \\
\text { Square }\end{array}$ & $\mathrm{F}$ & Sig. \\
\hline Regression & \multirow{3}{*}{\multicolumn{2}{|c|}{$\begin{array}{c}350,257 \\
9,879 \\
360,136\end{array}$}} & 1 & 350,257 & 5282,792 &, 000 \\
\hline Residual & & & 149 &, 066 & & \\
\hline Total & & & 150 & & & \\
\hline \multicolumn{7}{|c|}{$\begin{array}{l}\text { The independent variable is WCF. } \\
\text { The equation was estimated without the constant term. } \\
\text { Coefficients }\end{array}$} \\
\hline & \multicolumn{2}{|c|}{$\begin{array}{c}\text { Unstandardized } \\
\text { Coefficients }\end{array}$} & $\begin{array}{c}\text { Standardized } \\
\text { Coefficients }\end{array}$ & & & \\
\hline & B & $\begin{array}{l}\text { Std. } \\
\text { Error }\end{array}$ & Beta & $\mathrm{t}$ & Sig. & \\
\hline WCF & 2,508 &, 035 & ,986 & 72,683 & ,000 & \\
\hline $\mathrm{R}$ & \multicolumn{2}{|c|}{ R Square } & $\begin{array}{l}\text { Adjusted R } \\
\text { Square }\end{array}$ & $\begin{array}{l}\text { Std. Error } \\
\text { of the } \\
\text { Estimate }\end{array}$ & & \\
\hline ,986 & \multicolumn{2}{|c|}{,973 } & ,972 & 257 & & \\
\hline
\end{tabular}

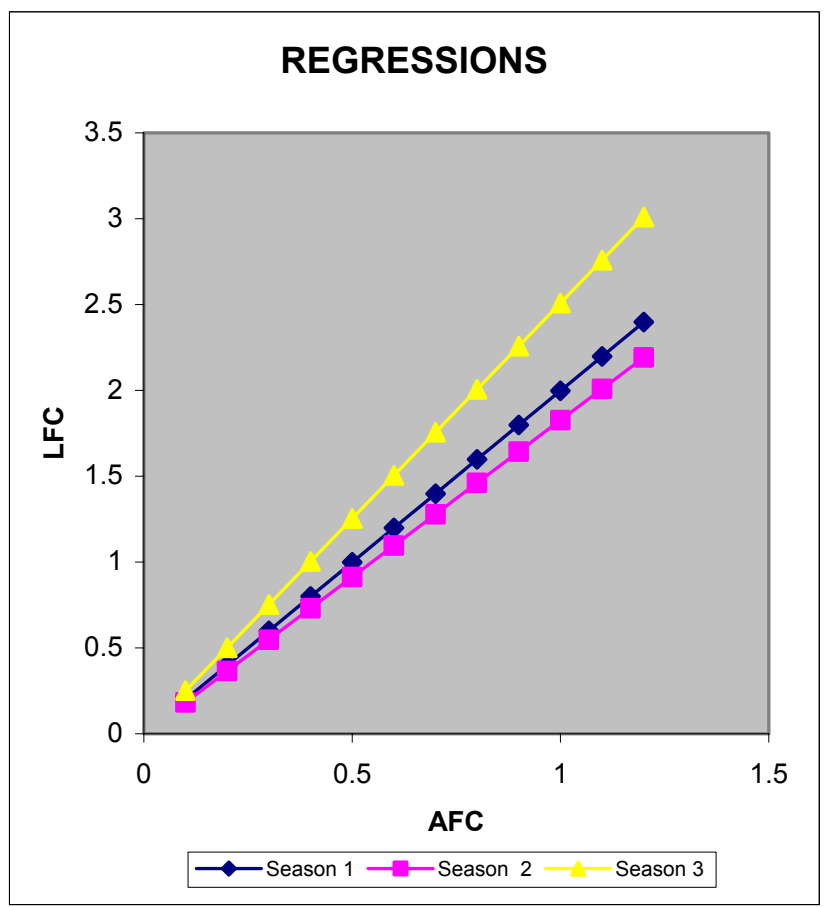

Figure 1: Regressions linear of the length in the seasons. 


\section{Conclusions}

The results obtained demonstrate that there is important variation in the size and shape of the central foliolae between the vegetative period and the start of the reproductive state.

The analyses of variance, using a completely random design with one factor i.e., seasons - carried out for each variable, detected significant differences (1\%) in all cases. For LCF, the largest measurement of $1.53 \mathrm{~cm}$ corresponded to season 3 , which was significantly different from measurements in the other two seasons, which did not show significant differences among themselves. As for the WCF, significant differences were detected for all the seasons (1, 2 and 3), with measurements of $0.68 \mathrm{~cm}, 0.78 \mathrm{~cm}$ and $0.60 \mathrm{~cm}$, respectively.

Analysis of the L/W ratio allowed for determination of the foliolae's shapes. During the winter period, seasons 1 and 2, the foliolae were narrowly obovate, while during the spring they were oblanceaolate. It has been established that in the former state the shape is narrowly obovate and in the second it is oblanceaolate. These conclusions are important because they constitute progress in the characterization of the new germplasm's central foliolae. Subsequent studies will make it possible to complete the list of requisites for achieving a complete characterisation needed for registration.

The results obtained allow us to conclude that there is a high level of variation in length and width, as well as the foliolae's shape and size, during the states of vegetative development (seasons 1 and 2) and the start of the reproductive state (season 3).

\section{Acknowledgement}

This work was supported in part by funds from AE/07/074 (YVE) from Generalitat Valenciana.

\section{References}

[1] Sácido, M. (2001). Pampa Deprimida Bonaerense, Descripción, Estado Actual y Manejo Sustentable. Primer Congreso Nacional sobre Manejo de Pastizales Naturales. Santa Fe, Argentina. 9-11de agosto. pp. 26-28.

[2] García, E., Rambeaud, D. E., Serpa, G. P. \& Serrano, P.M. (1994). Lotus tenuis Waldst et Kit.Un importante recurso forrajero para la Pampa Deprimida Argentina. Pergamino. Estación Agropecuaria. Boletín de Divulgación Técnica $\mathrm{N}^{\mathrm{o}}$ 102. pp. 20.

[3] Barufaldi, M., Villacampa, Y., Sastre-Vázquez, P. and Verdú F. (2007). A systems study of lotus's leaf area. Kybernetes. Vol 36, No2, pp. 225235 .

[4] Juan, V.; Monterroso, L.; Sácido M. and Cauhépé (2000). Postburning legume seeding in the Flooding Pampas, Argentina. Journal of Range Managent, 53, pp. 300-304. 
[5] Miñon, D., Sevilla, G., Montes, L. \& Fernández (1990). LOTUS TENUIS: leguminosa forrajera para la Pampa Deprimida. Boletín técnico $\mathrm{N}^{\circ}$ 98. INTA EEA, Balcarce. pp. 15.

[6] Kirbride, J. (1999). Lotus Systematics and Distribution. In: Trefoil: The Science and Technology. CSSA Special Publication Number 28. pp. 1-20.

[7] Barufaldi, M., Andrés, A., Crosta, H. \& Eseiza, M.(2000).Obtención de una población autotetraploide de Lotus glaber Mill. (Lotus tenuis Waldst. \& Kit). Revista de Tecnología Agropecuaria INTA Pergamino, Vol. V (15): pp.45-50. ISSN 0328-7750.

[8] Barufaldi, M. S., Crosta H., Eseiza, M., Cardozo, J., Schwab, M., Scenpio, V., Egoburo. D. ( 2002) .Evaluación preliminar del efecto de la poliploidía en Lotus glaber Mill. Taller interdisciplinario sobre aspectos genéticos, moleculares y ecofisiológicos del Lotus spp. y sus simbiontes. Sección: Taller de Mejoramiento Genético y Manejo de Cultivares. Organizado por el Instituto de Investigaciones Biotecnológicas -Instituto Tecnológico de Chascomús. IIB - INTECh / UNSAM - CONICET. Chascomús, 11-13 September.

[9] Urrea, C. and S. Singh. (1991). Variation for leaflet shape in wild and cultivated landraces of common bean. Ann. Rep. Bean Improv. Coop. $34: 13$

[10] Hickey, L. J. (1974). Clasificación de la arquitectura de las hojas de dicotiledóneas. Boletín de la Sociedad Argentina de Botánica. Vol. XVI (1-2): pp. 1-27. 